\title{
Use of colored agrotextiles and length of stay in the cultivation of yellow melons
}

\author{
Uso do agrotêxtil colorido e tempo de permanência no cultivo do melão amarelo \\ Uso de agrotextil de colores y duración de la stancia en el cultivo del melón amarillo
}

Received: 05/10/2021 | Reviewed: 05/17/2021 | Accept: 05/19/2021 | Published: 06/06/2021

\author{
Odair Honorato de Oliveira \\ ORCID: https://orcid.org/0000-0001-5462-241X \\ Federal University of Grande Dourados, Brazil \\ E-mail: odairhonorato2020@ gmail.com \\ Roberto Cleiton Fernandes de Queiroga \\ ORCID: https://orcid.org/0000-0002-7797-8408 \\ Federal University of Campina Grande, Brazil \\ E-mail: robertoqueiroga@ccta.ufcg.edu.br \\ Franciscleudo Bezerra da Costa \\ ORCID: https://orcid.org/0000-0001-6145-4936 \\ Federal University of Campina Grande, Brazil \\ E-mail: franciscleudo@yahoo.com.br \\ Evandro Franklin de Mesquita \\ ORCID: https://orcid.org/0000-0001-5722-2235 \\ State University of Paraíba, Brazil \\ E-mail: elmesquita4@uepb.edu.br \\ Francisco Alves da Silva \\ ORCID: https://orcid.org/0000-0001-9042-3039 \\ Federal University of Campina Grande, Brazil \\ E-mail: chico.lis@hotmail.com \\ Higínio Luan Oliveira Silva \\ ORCID: https://orcid.org/0000-0003-3624-6494 \\ Avant Agroquímica LTDA, Brazil \\ E-mail: hig_luan@hotmail.com \\ Álvaro Gustavo Ferreira da Silva \\ ORCID: https://orcid.org/0000-0001-8977-3808 \\ Federal University of Campina Grande, Brazil \\ E-mail: alvarogustavosilva@gmail.com
}

\begin{abstract}
The coverage of plants with agrotextiles of different colors and length of stay may influence the productivity of the crop. The objective of this study was to evaluate the influence of the use of colored agrotextiles and their length of stay on the cultivation of melon plants in the conditions of the semiarid region of Paraíba. The experiment was fulfilled out at the Experimental Farm of the Federal University of Campina Grande, located in the municipality of São Domingos - PB. The treatments were distributed in a randomized block design in a $4 \times 4$ factorial scheme, with four repetitions and consisting of four colors of agrotextile (orange, white, gray, and blue) and four lengths of stay $(15,18,21$, and 24 days after transplanting). The following characteristics were evaluated: active photosynthetic radiation, average temperature, number of fruits per plant, average fruit mass and total productivity. The use of colored agrotextiles associated with the length of stay promoted a change in the production characteristics of the yellow melon fruits. The highest productivity, number of fruits, and mass of the melon fruits were obtained when the plants were covered with the orange-colored agrotextile at 15, 18, and 24 days after transplantation, respectively. The long stay of the agrotextile affected the content of total soluble solids.
\end{abstract}

Keywords: Cucumis melo L.; Protected cultivation; Shading; Yield.

\section{Resumo}

A cobertura de plantas com agrotêxteis de diferentes cores e tempo de permanência pode influenciar na produtividade das lavouras. O objetivo deste trabalho foi avaliar a influência do uso de agrotêxteis coloridos e seu tempo de permanência no cultivo de melão nas condições do semiárido paraibano. $\mathrm{O}$ experimento foi realizado na Fazenda Experimental da Universidade Federal de Campina Grande, localizada no município de São Domingos - PB. Os tratamentos foram distribuídos em delineamento de blocos casualizados em esquema fatorial 4 x 4 , com 4 repetições e composto por quatro cores de agrotêxtil (laranja, branco, cinza e azul) e quatro tempos de permanência $(15,18,21$ e 24 dias após o transplantio). Foram avaliadas as seguintes características: radiação fotossintética ativa, temperatura média, número de frutos por planta, massa média do fruto e produtividade total. $\mathrm{O}$ uso de agrotêxteis coloridos associados ao tempo de permanência promoveu uma mudança nas características de produção dos frutos do melão amarelo. As maiores produtividades, número de frutos e massa dos frutos do melão foram obtidas quando as plantas 
foram cobertas com o agrotêxtil de cor laranja aos 15, 18 e 24 dias após o transplante, respectivamente. O tempo de permanência do agrotextil afetou o teor de sólidos solúveis totais.

Palavras-chave: Cucumis melo L.; Cultivo protegido; Sombreamento; Produção.

\section{Resumen}

La cobertura de plantas con agrotextiles de diferentes colores y duración de la estancia puede influir en la productividad de los cultivos. El objetivo de este trabajo fue evaluar la influencia del uso de agrotextil coloreados y su tiempo de permanencia en el cultivo de melón en las condiciones de la región semiárida de Paraíba. El experimento se llevó a cabo en la Finca Experimental de la Universidad Federal de Campina Grande, ubicada en la ciudad de São Domingos - PB. Los tratamientos se distribuyeron en un diseño de bloques al azar en un esquema factorial $4 \mathrm{x} 4$, con 4 repeticiones y compuesto por cuatro colores de agrotextil (naranja, blanco, gris y azul) y cuatro tiempos de permanencia $(15,18,21$ y 24 días después del trasplante). Se evaluaron las siguientes características: radiación fotosintética activa, temperatura promedio, número de frutos por planta, masa promedio de frutos y productividad total. El uso de agrotextil coloreados asociados a la tiempo de permanencia promovió un cambio en las características de producción de los frutos del melón amarillo. Los mayores rendimientos, número de frutos y masa de frutos de melón se obtuvieron cuando las plantas se cubrieron con el agrotextil de color naranja a los 15, 18 y 24 días después del trasplante. El tiempo de permanencia del agrotextil afectó el contenido de sólidos solubles totals.

Palabras clave: Cucumis melo L.; Cultivo protegido; Sombreado; Producción.

\section{Introduction}

Melon is a plant grown in several countries and has been recorded in Europe, Asia, Africa, and North and South America (Silva et al. 2018). According to FAO (2019), melon production in the world in 2017 was 31,948.349 million tons. Of this total, Brazil produced 540,229 thousand tons of fruit and, in the Northeast region of Brazil, mainly in Chapada do Apodi (RN) and Baixo Jaguaribe (CE), stood out as the central producing locations corresponding to $72.4 \%$ of the melon produced in the country (IBGE, 2019).

This species is considered a C3 cycle plant; however, it demands solar radiation and temperature. In this context, the semiarid region of Northeast Brazil stands out as promising for the cultivation of melon due to the record of high radiation levels that can exceed 3,000 h of sunlight in the year (Pereira et al. 2015). On the other hand, excessive sunlight on plants can be prejudicial to photosynthesis because the efficiency of the photosynthetic process is severely reduced in these conditions, after all, when the leaves are exposed to more light than they can use, that is, above from the saturation point, the photosynthetic apparatus is damaged and becomes inactive due to photoinhibition (Brant et al. 2011).

It is of fundamental importance to adopt technologies that mitigate the detrimental effects of high levels of solar radiation on plants. Melon producers use white-colored agrotextile. However, there is a need for research that can assess the association of agrotextile colors and the length of stay on the characteristics of plants such as growth and fruit production.

For Taiz and Zeiger (2017), the color spectrum can positively or negatively influence the functionality of plant organs. Thus, changes in the microclimate introduced in the cultivation of melon by the use of agrotextile with different colors and time of permanence, especially to the reduction of solar radiation, wind speed, air temperature, and increased absolute humidity, can decrease the evaporative demand in the plants and allow the plants to increase stomatal conductance and, therefore, $\mathrm{CO}_{2}$ assimilation in comparison with the open field ones in the initial growth phase (Haijun et al. 2015).

Saraiva and Rodrigues (2012) evaluated Pepino Taiko's initial development that the colored meshes (blue, red, and black) influence the initial development and the physiological and metabolic activities. Costa et al. (2010) also observed changes in the anatomy of the leaves, such as less thickness of the adaxial epidermis and palisade parenchyma, fewer stomata and morphology such as the height of plants of the species Ocimum selloi as a function of the color spectrum of the meshes (red and blue).

Thus, the covering of the plants in the cultivation line with colored meshes can alter the physiological responses of the plants, modifying the production of photoassimilates and the source: drain off the plants. The length of stay of the agrotextile 
can also influence the development of the crop; Santos et al. (2015), in a study with the culture of melon, observed that the treatments with the use of line cover influenced the firmness of the pulp and showed a linear increase of $35.2 \%$ compared to the control at 30 days, while the total acidity was titratable, soluble solids and total soluble sugars decreased $33.3,8.9$, and $42.1 \%$, respectively, with the increase in the coverage time in the plants. The objective of this experiment was to evaluate the melon production characteristics according to the association of the colored agrotextile and length of stay.

\section{Methodology}

The work was carried from October 2018 to January 2019 at the Experimental Farm of the Federal University of Campina Grande (UFCG) in São Domingos - Paraíba, Brazil. A randomized block design in a 4 x 4 factorial with four replications was used. The treatments consisted of four colors (orange, white, gray, and blue) and four lengths of stay of agrotextile $(15,18,21$, and 24 days after transplantation - DAT). The parcel area contained ten plants and a functional area with eight plants, respectively.

On October 30, 2018, the sowing took place in expanded polystyrene trays of 128 cells filled with commercial substrate indicated for the production of vegetable seedlings. The transplant was carried out when the seedlings presented the second final leaf emitted, using the spacing of $2.0 \times 0.5 \mathrm{~m}$ with one plant per hole a hybrid of yellow melon, from the Inodorus group of the company Feltrin ${ }^{\circledR}$.

The experimental area was $1600 \mathrm{~m}^{2}$, in which a plowing and subsequent opening of the planting furrows spaced by $2.0 \mathrm{~m}$, raising the swaths with $0.20 \mathrm{~m}$ the height and width of $0.30 \mathrm{~m}$ adopted for the preparation of the soil. The management of planting and cover fertilization was carried out according to soil analysis and the recommendations for the crop (Cavalcanti et al. 2008). In planting fertilization, $120 \mathrm{~kg} \mathrm{ha}^{-1}$ of $\mathrm{P}_{2} \mathrm{O}_{5}$ were applied in $100 \%$ to the foundation using simple superphosphate, together with $10 \%$ of $\mathrm{N}$ and $\mathrm{K}_{2} \mathrm{O}$, in the forms of urea and potassium chloride in the amount of $120 \mathrm{~kg} \mathrm{ha}^{-1}$, respectively. Three days after the transplantation, fertilization of cover initiated, where $90 \% \mathrm{~N}$ and $\mathrm{K}_{2} \mathrm{O}$ were used via fertigation with daily applications for seven subsequent weeks. In each fertigation, the following nutrients and quantities were applied weekly: 1st week $=5.0 \% \mathrm{~N}$ and $10.0 \% \mathrm{~K}_{2} \mathrm{O} ;$ 2nd week $=10.0 \% \mathrm{~N}$ and $10.0 \% \mathrm{~K}_{2} \mathrm{O} ; 3$ rd week $=15.0 \% \mathrm{~N}$ and $15.0 \% \mathrm{~K}_{2} \mathrm{O}$; 4th week, 5th and 6th weeks $=20.0 \% \mathrm{~N}$ and $18.0 \% \mathrm{~K}_{2} \mathrm{O}$; 7th week $=10.0 \%$ of $\mathrm{N}$ and $11.0 \%$ of $\mathrm{K}_{2} \mathrm{O}$.

The melon was kept in a closed tunnel with the agrotextile of different colors with a width of $1.38 \mathrm{~m}$ and a weight of $15 \mathrm{~g} \mathrm{~cm}^{-2}$, being removed according to the proposed treatments. Irrigation was performed using the localized method with drippers spaced $0.5 \mathrm{~m}$ apart and a flow rate of $2.0 \mathrm{~L} \mathrm{~h}^{-1}$. After removing the agrotextile, manual weeding and preventive phytosanitary control were performed.

The harvest was carried out on January 15, 18, and 21, 2019. The fruits were harvested when they had an intense yellow color and uniform size. Weekly assessments were carried out until the removal of agrotextile at 24 days DAT of photosynthetically active radiation (RFA) with an Accupar LP-80 model ceptoometer, temperature, and relative air humidity with an HT-210 digital thermohygrometer. The following characteristics were evaluated in the harvest of the melon fruits: number of fruits per plant by counting all the fruits produced by the util area; average fruit mass (g.fruit ${ }^{-1}$ ) by weighing the fruits of the valuable area of each treatment on a digital scale divided by the number of fruits, the total productivity of the fruits produced in the valuable area of the plot $\left(\mathrm{t} \mathrm{ha}^{-1}\right)$ by the estimate for $1 \mathrm{ha}^{-1}$ at the experimental level and total soluble solids (SST) using of a portable digital refractometer, model Atago $\mathrm{PAL}^{-1}$, obtaining the values in percentage.

The collected data were submitted to analysis of variance in the SAEG 9.0 software at the level of 5\% probability. For the colors of the agrotextile, the Tukey test at $5 \%$ probability was used, and for the length of stay of the agrotextile on the plants, regression analysis using the Table Curve 2D software. 


\section{Results}

There was a significant effect of the interaction of the factors of the color of the agrotextile and length of stay on the plants for characteristics of the number of fruits per plant, average fruit mass, and total productivity $\mathrm{p}<0.05$. In the variables related to climate, only the reduction in radiation and temperature below the agrotextile was performed.

In this work, it is possible to observe that the blue, gray, orange and white agrotextile caused a reduction of 73.3, 65.9, 61.5 , and $36.2 \%$ in the photosynthetic active radiation below the agrotextile, respectively. This fact, possibly, led to a greater reduction in temperature below the agrotextile of $27.3 \%$ and $23.5 \%$ in the colors blue and gray. However, the use of white agrotextile was more effective in reducing the temperature below $(22.7 \%)$ than that of orange $(20.5 \%)$, possibly due to the greater reflectance and less heat absorption in the white-colored agrotextile (Table1).

Table 1 - Reduction of radiation and temperature $(\%)$ due to the different colors of agrotextile in the cultivation of yellow melon. UFCG, Pombal - Paraíba.

\begin{tabular}{ccc}
\hline Agrotextile colors & $\begin{array}{c}\text { Reduction of radiation below the } \\
\text { agrotextile }(\%)\end{array}$ & $\begin{array}{c}\text { Reduction of the temperature below the } \\
\text { agrotextile }(\%)\end{array}$ \\
\hline Orange & 61,5 & 20,7 \\
White & 36,2 & 22,7 \\
Gray & 65,9 & 23,5 \\
Blue & 73,3 & 27,3 \\
\hline
\end{tabular}

Source: Authors.

When studying, the effect of the color of the agrotextile within each length of stay on the plants, about the number of fruits, registered a more value when the plants were covered with orange agrotextile at 15 and 18 DAT, respectively; at 21 DAT, the most significant number of fruits were obtained with the cover with white agrotextile, and at 24 DAT there were no significant differences in the number of fruits in the plant regardless of the color of the agrotextile (Table 2).

The average fruit mass was higher when the plants were covered with gray at 15 DAT, with the plants covering with blue agrotextile and gray at $18 \mathrm{DAT}$, and orange at $24 \mathrm{DAT}$. At the same time, at 21.0 DAT, there was no significant difference in the number of fruits in the plant due to the use of the agrotextile in its different colors (Table 2). 
Table 2 - Study of the number of fruits and the mass of the fruit of the yellow melon unfolding the interaction of the color of the agrotextile within each length of stay of agrotextile on the plant. UFCG, Pombal - Paraíba.

\begin{tabular}{|c|c|c|c|c|}
\hline \multirow{3}{*}{ Length of stay of agrotextile (DAT) } & \multicolumn{4}{|c|}{ Number of fruits per plant } \\
\hline & \multicolumn{4}{|c|}{ Agrotextile colors } \\
\hline & Orange & White & Gray & Blue \\
\hline 15 & $2,49 \mathrm{a}$ & $1,71 \mathrm{~b}$ & $2,12 \mathrm{~b}$ & $1,42 \mathrm{~b}$ \\
\hline 18 & $2,58 \mathrm{a}$ & $1,77 \mathrm{~b}$ & $1,08 \mathrm{c}$ & $1,05 \mathrm{c}$ \\
\hline 21 & $1,54 \mathrm{~b}$ & $1,92 \mathrm{a}$ & $1,00 \mathrm{c}$ & $0,92 \mathrm{c}$ \\
\hline 24 & $0,67 \mathrm{a}$ & $0,75 \mathrm{a}$ & $0,83 \mathrm{a}$ & $0,88 \mathrm{a}$ \\
\hline $\mathrm{CV}(\%)$ & \multicolumn{4}{|c|}{13,59} \\
\hline SMD & \multicolumn{4}{|c|}{0,36} \\
\hline \multirow{3}{*}{ Length of stay of agrotextile (DAT) } & \multicolumn{4}{|c|}{ Average fruit mass (g.fruto ${ }^{-1}$ ) } \\
\hline & \multicolumn{4}{|c|}{ Agrotextile colors } \\
\hline & Orange & White & Gray & Blue \\
\hline 15 & $1494,79 \mathrm{~b}$ & $1356,26 \mathrm{~b}$ & $1789,59 \mathrm{a}$ & $1468,64 \mathrm{~b}$ \\
\hline 18 & $1589,55 \mathrm{ab}$ & $1364,60 \mathrm{~b}$ & $1704,80 \mathrm{a}$ & $1856,68 \mathrm{a}$ \\
\hline 21 & 1653,19 a & $1530,21 \mathrm{a}$ & $1698,94 \mathrm{a}$ & 1689,38 a \\
\hline 24 & $2127,57 \mathrm{a}$ & $1597,95 \mathrm{~b}$ & $1656,77 \mathrm{~b}$ & $1610,74 \mathrm{~b}$ \\
\hline $\mathrm{CV}(\%)$ & \multicolumn{4}{|c|}{9,44} \\
\hline SMD & \multicolumn{4}{|c|}{291,65} \\
\hline
\end{tabular}

* Means followed by the same letter on the column do not differ at the $5 \%$ probability level by the Tukey test. SMD - Significant mine difference. CV - coefficient of variation. Source: Authors.

The study of the residence time within each color of the agrotextile is shown in Figure 1. We can see that the number of fruits per plant showed a quadratic response in the different colors with maximum estimated values of 2.6, 1.9, 2, 1 and 1.4

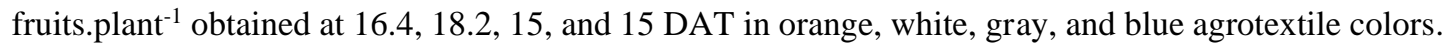

Figure 1 - Study of the number of fruits and the mass of the fruit of the yellow melon dividing the interaction of the length of stay within each color of the agrotextile. $(\mathrm{O}=$ orange, $\mathrm{W}=$ white, $\mathrm{G}=$ gray, and $\mathrm{B}=$ blue $)$. CCTA/UFCG, Pombal - Paraíba.
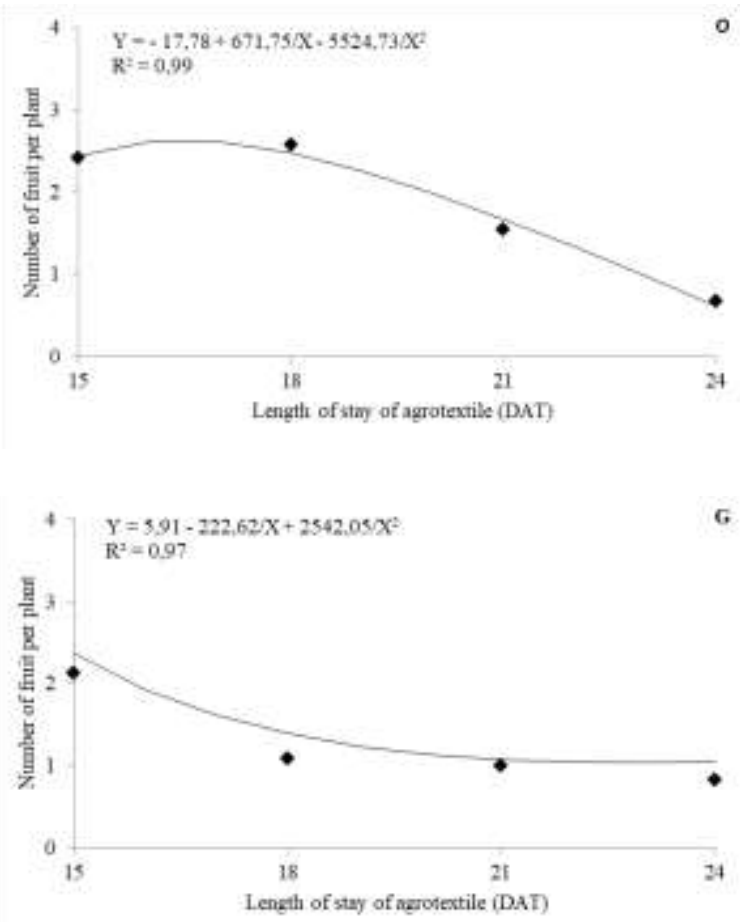
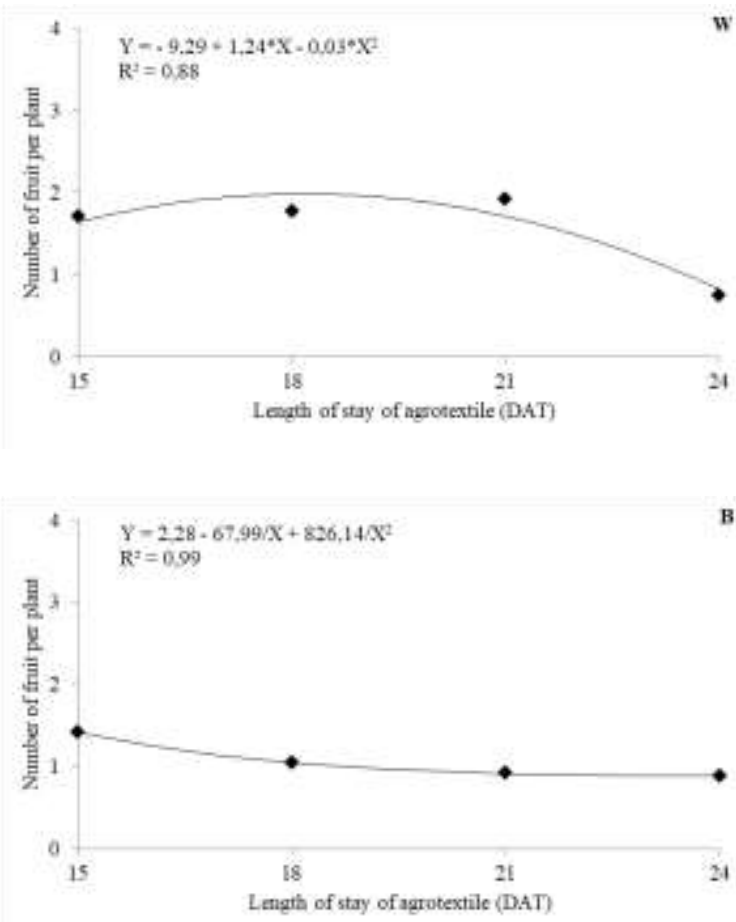

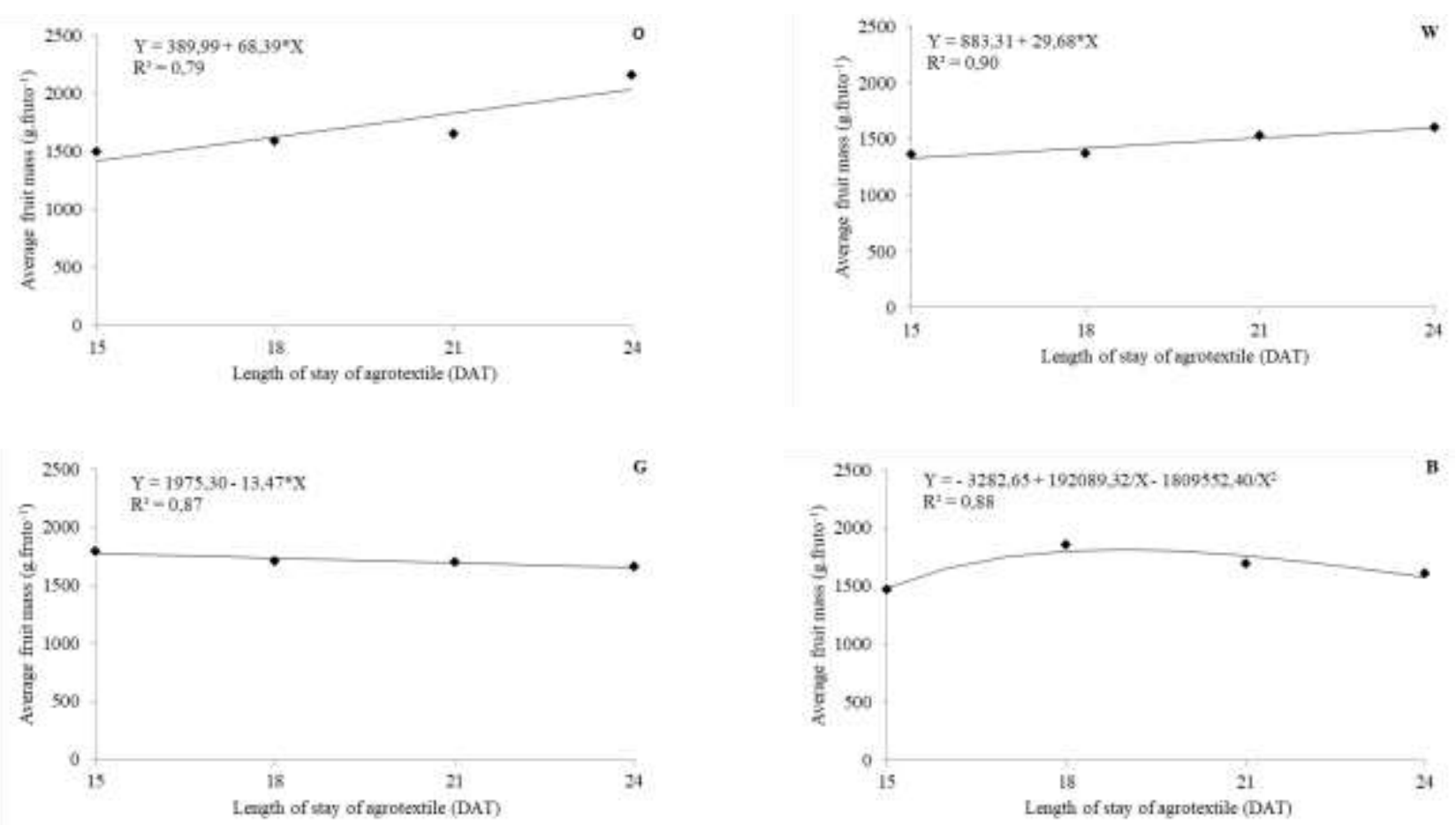

Source: Authors.

As for the average fruit mass, an increasing linear response recorded with estimated maximum values of 2,031.6 and 1,595.9 g.fruit $^{-1}$ at the 24 DAT of the permanence of the orange and white agrotextile. Comparing the removal of agrotextile 15 DAT, there was an increase the mass of the fruit of 30.3 and $16.4 \%$, respectively. The gray-colored and inversely proportional behavior was found to increase the agrotextile permanence time until 24 DAT with an estimated value of 1,651.8 g.fruit ${ }^{-1}$ obtained at 15 DAT this reduction in the average fruit mass was $6.8 \%$. Lastly, was blue-colored agrotextile obtained a quadratic response with an estimated maximum value of 1,815.1 g.fruit ${ }^{-1}$ to 18.8 DAT of permanence on the plants (Figure 2).

In addition to the plant population in the area, the number of fruits per plant and the average fruit mass are two variables that significantly influence the formation of melon productivity. In the evaluation of this characteristic, we can observe greater total productivity of the yellow melon of the Inodorus group with the permanence of the agrotextile on the plants until 15 DAT when with orange and gray colors was used, at 18 DAT with greater productivity with the agrotextile of orange color, at 21 DAT with higher productivity with the colors orange and white. In comparison, at 24.0 DAT, there were no significant differences in total productivity due to the use of agrotextile with its different colors in melon cultivation yellow in the semiarid conditions of Paraíba (Table 3). 
Table 3 - Study of the productivity of yellow melon unfolding the interaction of the color of the agrotextile within each length of stay on the plants. UFCG, Pombal - Paraíba.

\begin{tabular}{ccccc}
\hline & \multicolumn{4}{c}{ Productivity t.ha $^{-1}$} \\
\cline { 2 - 5 } Length of stay of agrotextile (DAT) & \multicolumn{4}{c}{ Agrotextile colors } \\
\cline { 2 - 5 } & Orange & $23,09 \mathrm{~b}$ & $37,71 \mathrm{a}$ & $20,30 \mathrm{~b}$ \\
15 & $36,15 \mathrm{a}$ & $24,30 \mathrm{~b}$ & $18,70 \mathrm{c}$ & $19,52 \mathrm{bc}$ \\
18 & $40,73 \mathrm{a}$ & $29,10 \mathrm{a}$ & $16,88 \mathrm{~b}$ & $15,39 \mathrm{~b}$ \\
21 & $25,31 \mathrm{a}$ & $13,79 \mathrm{a}$ & $14,14 \mathrm{a}$ \\
\hline CV $(\%)$ & $14,33 \mathrm{a}$ & \multicolumn{3}{c}{12,51} \\
\hline SMD & \multicolumn{3}{c}{5,32} \\
\hline
\end{tabular}

* Means followed by the same letter on the line do not differ at the $5 \%$ probability level by the Tukey test. SMD - Significant mine difference. CV - coefficient of variation. Source: Authors.

When carrying out the study of the different length of stay agrotextile within each color of the material, we can evidence a quadratic response in melon productivity with maximum estimated values of 40.31 and 28.25 t.ha ${ }^{-1}$ at 16.7 and 18.6 DAT in the colors of the orange and white, respectively. Regarding the permanence time of the 15 DAT, there was an increase of 10.4 and $18.3 \%$ in melon productivity. On the other hand, the permanence of the agrotextile until 24 DAT in orange and white colors reduced melon productivity by 66.8 and $53.7 \%$, respectively (Figure 2).

For plants that were covered with gray and blue colored agrotextile, a decreasing linear response was observed; that is, melon productivity decreased with the increase of the length permanence on the plants until 24 DAT. In this case, melon productivity decreased from 37.36 to 14.35 t.ha $^{-1}$ and 20.73 to 13.96 t.ha ${ }^{-1}$, representing a decline of $61.4 \%$ and $32.7 \%$ agrotextile in gray and blue, respectively (Figure 2).

Figure 2 - Study of the productivity of the yellow melon dividing the interaction of the color of the agrotextile within each length of stay agrotextile on the plants $(\mathrm{O}=$ orange, $\mathrm{W}=$ white, $\mathrm{G}=$ gray, and $\mathrm{B}=$ blue $)$. UFCG, Pombal - Paraíba.
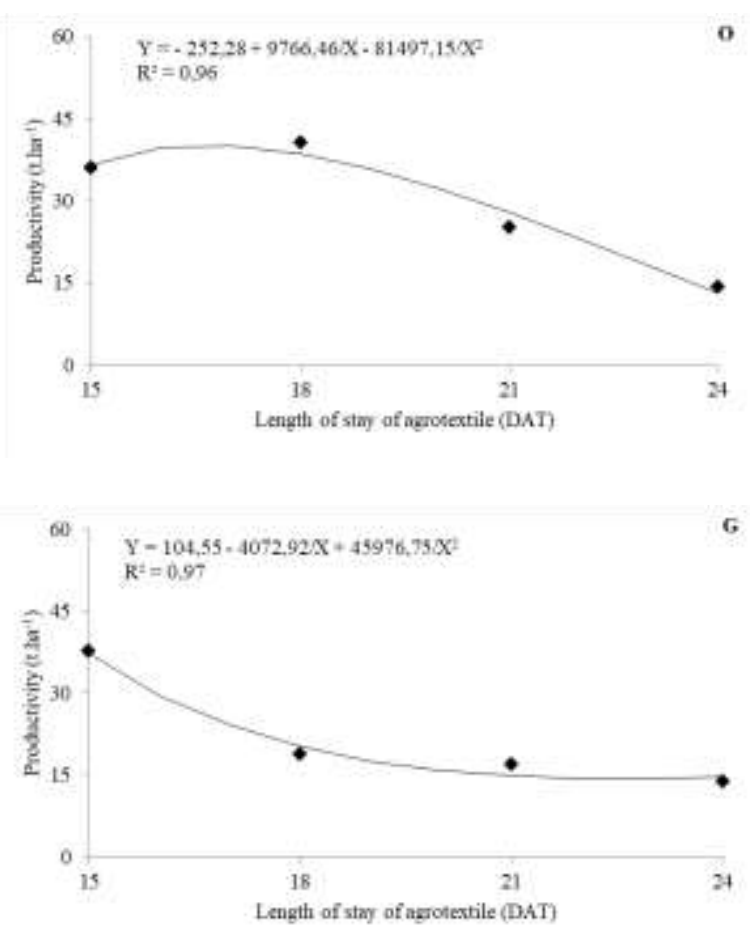
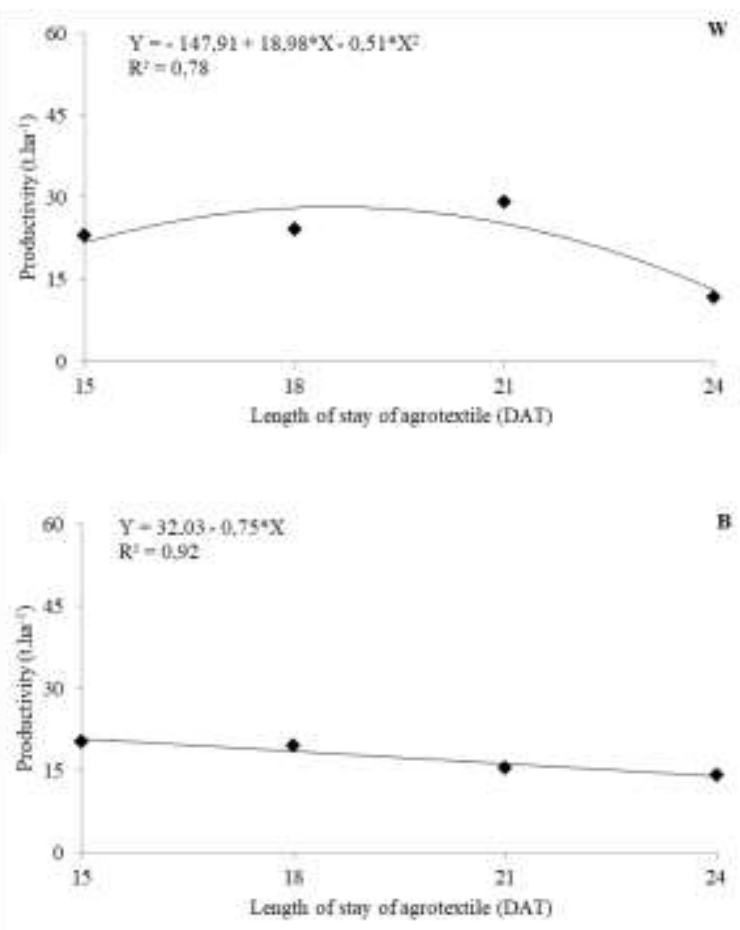
Regarding the content of total soluble solids, no significant difference was observed in the extract extracted from the fruit pulp due to the use of different colors (Table 9). The stay of the agrotextile was 24.0 DAT, and it was still in the initial flowering stage where the presence of fruits was not observed. Thus, the increase in the leaf area of plants grown under different colors don changed the growth of the fruits in terms of mass; however, it had less influence on the accumulation of soluble solids from the fruits.

Table 4 - Average values for total soluble solids $\left(\mathrm{Brix}^{\circ}\right)$ of the yellow melon fruit according to the colors of the agrotextile. UFCG, Pombal - Paraíba.

\begin{tabular}{cc}
\hline Agrotextile colors & Total soluble solids $\left(\right.$ Brix $\left.^{\circ}\right)$ \\
\hline Orange & $12,32 \mathrm{a}$ \\
White & $12,01 \mathrm{a}$ \\
Gray & $12,27 \mathrm{a}$ \\
Blue & $12,08 \mathrm{a}$ \\
\hline CV $(\%)$ & 5,34 \\
\hline SMD & 0,61 \\
\hline
\end{tabular}

* Averages followed by the same letter in the columns do not differ at the level of 5\% probability by the Tukey test. SMD - Significant mine difference. CV - coefficient of variation. Source: Authors.

When taking into account their length of permanence, it was found that for total soluble solids, a quadratic response was found, with an estimated maximum value of $12.5 \%$, obtained at 17.0 DAT, which generated an increase of $0,1 \%$ in total soluble solids; from that time the agrotextile remained under the plants, which allowed a reduction in its value of $8.5 \%$ to the 24.0 DAT (Figure 8).

Figure 3 - Study of the total soluble solids of the yellow melon as a function of the length of stay of the colored agrotextile. UFCG, Pombal - Paraíba.

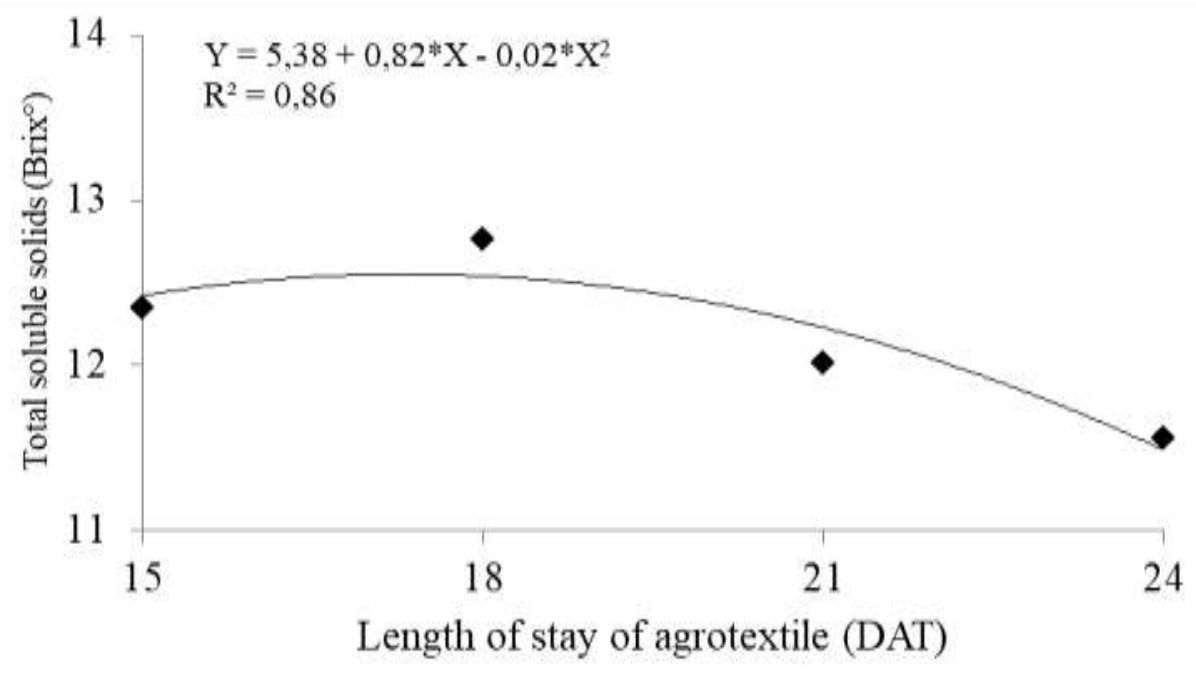

Source: Authors.

\section{Discussion}

Among the factors related to climate, radiation and temperature are two climatic variables essential for plants' proper growth and development. Despite being a C3 plant, the melon tree needs high levels of radiation and temperature to reach its maximum production potential. 
This significant reduction in radiation and temperature levels is directly related to the color since the agrotextile in the colors blue and gray compared to the white color shows a condition of more shading, affecting the passage of the sun's rays and, consequently, the temperature. According to Mahmood et al. (2018), the shading effect of color screens reduces the amount of radiant energy received and can reduce air temperature.

Because of the results found, we can observe that the permanence of the agrotextile at 15 and 18 DAT in orange color increased the number of fruits in the plant and reduced its average mass. An inverse result was observed when the plants were covered with gray in which a smaller number of fruits were observed in the plant and a higher average mass at 15 and 18 DAT. At 21 DAT, the coverage with white agrotextile stood out in increasing the number of fruits; however, there was no difference between the other agrotextile colors regarding the average mass. At 24 DAT, the result was the opposite, where no significant differences were observed in the number of fruits in the plant, but the mass of the fruit was more significant when the plants were covered with orange-colored agrotextiles. According to Pereira et al. (2017), the most significant number of fruits per plant generates competition between these and the vegetative organs, decreasing the latter's growth; however, this effect can be reduced when there is no limitation of solar radiation.

These results have a direct effect related to the color orange, which has a wave range $(590-620 \mathrm{~nm})$ very close to the color red (620-750 nm) (Taiz; Zeiger, 2017). Tafoya et al. (2018) studied the effects of colored screens on cucumber cultivation and observed that the blue and red nets provided a greater density of the photon flow. According to these authors, light levels favored photosynthesis, which led to an increase in biomass production, which implies a larger leaf area and greater efficiency in the transport of photoassimilates and greater reserve capacity assimilates for later use in the filling of fruits.

In commercial melon crops in the central producing regions of Brazil, the use of the agrotextile is up to 24 DAT and in white color, aiming, above all, to protect the plants against the attack of whitefly (Bemisia Tabaci) and miner fly (Liriomyza spp.). In this sense, we can observe that the cover of the plants with orange-colored agrotextile, despite not having contributed to increasing the number of fruits in the plant compared to the other colors, was efficient in raising its average mass, standing out about other colors of the agrotextile.

About the number of fruits per plant, the permanence of the agrotextile until 15 DAT led to an increase of 7.6 and $13.6 \%$ to 16.4 and 18.2 DAT, in the colors of orange and white, respectively. In these two colors of orange and white, their maintenance on plants until 24 DAT resulted in a reduction of 76.8 and $54.8 \%$ in the number of fruits. In the gray and blue agrotextile colors, the permanence on the plants for a long time until 22.5 and 24 DAT reduced number of fruits on the plant by 59.5 and $37.6 \%$, respectively.

This minor reduction in the number of fruits per plant of $37.6 \%$ observed in plants that received the blue colored agrotextile may be due to the better condition in the initial growth phase until 18 DAT in incident radiation, temperature, and its larger leaf area. However, Taiz and Zeiger (2017) state that the blue color provides better efficiency in stomatal opening and $\mathrm{CO}_{2}$ uptake and consequently conversion into photoassimilate for fruit about other material colors.

It is observed that the use of agrotextile independent of the colors used when remaining on melon plants until 24 DAT provided a reduction in the number of fruits. This behavior may be associated with the shading of the plant's canopy during the vegetative phase, responsible for the accumulation of photoassimilate that will be used in the production of flowers and, consequently, fruits (Pereira et al. 2017).

An enormous mass of the fruit in plants that received the orange and white agrotextile at 24 DAT was due to the lower number of fruits per plant. In melon, the increase in the number of fruits per plant contributed to a reduction in the average mass due to competition for assimilates (Queiroga et al. 2009). In addition, the larger leaf area (data not shown) in plants that received the orange agrotextile cover at 24 DAT may have increased the production and transport of photoassimilates aimed at 
fruit growth. This fact may also have occurred due to the longer exposure time to the orange color, which presents a waveband (590-620 nm) very close to the red color (620-750 nm), which the plant uses most of the energy received ( Taiz; Zeiger 2017).

In the coverage of plants with white agrotextile, there was a smaller reduction in radiation and temperature of 36.2 and $22.7 \%$, respectively, which led to a lower gain in the mass of the fruit of $16.4 \%$. Mahmood et al. (2018) report that the whitecolored networks showed high transmittance to solar radiation (above 60.0\%), together with their significant reflectance (24.0\%) and low absorption (13.0\% to $15.0 \%)$.

The more intense colored agrotextile, gray and blue, provided higher values of fruit mass when they remained on the plants for a shorter period of 15 and 18.8 DAT, respectively. This fact may be associated with modifying the spectral quality through the colored agrotextile used, thus acting as a physiological tool modifying the microenvironment of the cultures (Ilić; Fallik, 2017).

Plants covered with agrotextile in gray and blue colors were subjected to a more shading of 65.9 and $73.3 \%$ and a more significant reduction in temperature below the coverage of 27.3 and $23.5 \%$, respectively. These climatic data show the importance of studying shading in melon crops, especially under conditions of excessive solar radiation and its effects on plant growth and development. Pereira et al. (2017), working with the melon culture under a white agrotextile, observed that removal of the line cover during the beginning of plant growth at 20 DAT when compared to removal performed at 24.0, 28.0, and 36.0 DAT it was advantageous for the crop, as it allowed the plant to be exposed to higher solar radiation raising the average mass of the fruit.

Crop productivity depends on other factors, such as the number of fruits per plant and the mass of the fruits. In general, it was observed that the highest values of crop productivity were registered when the plants were covered with orange agrotextile at 15 and 18 DAT due to the more significant number of fruits and 21 and 24 DAT due to their more mass average in these conditions. In this case, it is evident that when the number of fruits in the plant is increased, a reduction in its mass is expected due to the greater intraspecific competition in the plant, especially between fruits in formation.

As observed in the orange-colored agrotextile, higher productivity values were also observed with the permanence of the agrotextile for up to $15 \mathrm{DAT}$ when the plants were covered with gray colors due to the greater mass of the fruit observed in this condition, at 21 DAT with white due to the more significant number of fruits per plant. However, the cover of the plants with blue colored reduced the productivity of the crop until 21 DAT, mainly due to the lower averages of the number of fruits per plant. Lastly, at the 24 DAT of the permanence of the agrotextile on the plants, the productivity did not vary significantly due to the different colors due to the non-variation of the number of fruits per plant, despite the higher average mass obtained from fruits of plants covered with orange colored agrotextile.

Oren-Shamir et al. (2001) observed that colored meshes present a difference in the transmittance spectrum of active photosynthetic radiation. Thus, the wavelength influences the growth and development of the plant, as it is directly connected with the production of photoassimilate that is allocated for the fixation and growth of the fruit.

In addition, the level of shading and quality of light may have influenced the lower yield of the crop in plants covered with blue agrotextile and the higher yield of the crop in plants covered with orange agrotextiles. According to Ombódi et al. (2015), the photoselective shading of red and yellow nets markedly increases productivity, improves the fruits of different vegetables, and reduces the infestation of pests and diseases. According to Taiz and Zeiger (2017), the blue mesh shows a transmittance peak in the blue-green region (400-540nm), while the red-orange mesh has higher transmittance for wavelengths greater than $(590-620 \mathrm{~nm})$, which is a more suitable band for the cultivation of melon.

In the coverage with agrotextile with lighter colors, in other words, orange and white, where the reduction of radiation was lower below the coverage, greater productivity was found. In plants covered with more intense colors, gray and blue, the shading affects crop productivity more. According to Stanghellini et al. (2011), the restriction of solar radiation and affecting 
the components of the energy balance, such as sensitive and latent heat flows, can influence the growth, development, and production of crops.

In all colors of the agrotextile it was evidenced that its permanence until 24 DAT reduced the productivity of the melon with a more significant effect on the cover with blue colors. This fact may have occurred due to the longer time and level of shading that the plants were under the protection of the agrotextile. This lower light intensity probably reduced photosynthesis in the plant, with effects on the crop's productivity.

The total soluble solids content of the melon fruits was reduced by $8.5 \%$ with the delay in removing the agrotextile, as the plants that remained longer time shaded. Such observed behavior is probably due to the more extended period of permanence at 24.0 DAT, allowing the plant to receive less radiation, which contributed to the reduction of photosynthetic activity, less growth, production, and translocation of photoassimilates directed to the sweetening of the fruits.

In the proposed treatments, the average values of soluble solids obtained were above the minimum required by importers, $8.0 \%$ (FFV-23). It is essential to highlight that even the later withdrawal of the agrotextile did not leave the soluble solids below the import requirement. Thus, in markets demanding more sweet fruits, this can be a differential factor of the product with the consumer.

FAO (1990) cites the global solar radiation level of $8.4 \mathrm{MJ} \mathrm{m}^{-2}$.day ${ }^{-1}$ as a light compensation point for vegetables. This value is sufficient to guarantee the minimum production of photoassimilates necessary for the maintenance of the plant. The photic saturation point, which establishes the limit level of photosynthetically active radiation up to which an increase in $\mathrm{CO}_{2}$ assimilation occurs, must be observed. In the present experiment, under conditions of levels of photosynthetically active radiation below the necessary, occurring in the different colors of the agrotextile, especially in the cover with the blue color, the lower limit can restrict photosynthesis and, above, they can promote the excessive temperature increase in the plant, with adverse effects on the transpiratory and photosynthetic rate and thereby reduce melon productivity.

\section{Conclusion}

The production characteristics of yellow melon fruits were changed due to the use of colored agrotextiles associated with the length of stay under the plants;

The highest productivity, number of fruits, and mass of the melon fruits were obtained with the permanence of the agrotextile for 15.0, 18.0, and 24.0 days after the transplant, respectively, when the plants were covered with the orangecolored agrotextile.

Local farmers use the white-colored agrotextile, however, this coloration of the material proved to be less effective than the orange color in terms of increasing crop productivity.

The soluble solids content was affected due to the length of stay, but the colors did not affect the soluble solids content.

\section{Acknowledgments}

Coordination for the Improvement of Higher Education Personnel - Brazil (CAPES) - for the scholarship to the first author and to the employees of the Experimental Farm at the Federal University of Campina Grande for all the support in the development of the research.

\section{References}

Brant, R. S., Pinto, J. E. B. P., Rosal, L. F., Alves, C., Oliveira, C. \& Albuquerque, C. J. B. (2011). Adaptações fisiológicas e anatômicas de Melissa officinalis L. (Lamiaceae) cultivadas sob malhas termorrefletoras em diferentes intensidades luminosas. Revista Brasileira Plantas Medicinais, 13 , 467-474. 
Cavalcanti, F. J. A. et. al. Recomendações de adubação para o Estado de Pernambuco. 2a Aproximação. Instituto Agronômico de Pernambuco - IPA, 2008. 212p. Il.

Costa, L. C. B., Pinto, J. E. B., Castro, E. M., Alves, E., Bertolucci, S. K. V. \& Rosal, L. F. (2010). Effects of coloured shade netting on the vegetative development and leaf structure of Ocimum selloi. Bragantia, 69, 349-359.

FAO - Organização das Nações Unidas para Alimentação e Agricultura. http://www.fao.org/faostat/es/\#data/QC

Haijun, L., Cohen, S., Lemcoff, J. H., Israeli, Y. \& Tanny, J. (2015). Sap flow, canopy conductance and microclimate in a banana screenhouse. Agricultural and Forest Meteorology. 201, 165-175.

IBGE - Instituto Brasileiro de Geografia e Estatística. https://censos.ibge.gov.br/agro/2017/

Ilić, S. Z. \& Fallik, E. (2017). Light quality manipulation improves vegetable quality at harvest and postharvest: A review. Environmental Experimental Botany. 139, 79-90. http://dx.doi.org/10.1016/j.envexpbot.2017.04.006

Mahmood, A., Hu, Y., Tanny, J. \& Asante, E. A. (2018). Effects of shading and insect-proof screens on crop microclimate and production: A review of recent advances. Scientia Horticulturae. 241, 241-251. https://doi.org/10.1016/j.scienta.2018.06.078

Ombódi, A., Pék, Z., Szuvandzsiev, P., Tóthné Taskovics, Z., Koházi-Kis, A., Kovács, A., Ledóné Darázsi, H. \& Helyes, L. (2015). Effects of External Coloured Shade Nets on Sweet Peppers Cultivated in Walk-in Plastic Tunnels. Notulae Botanicae Horti Agrobotanici, 43, 398-403. DOI:10.15835/nbha4329863

Oren-Shamir, M., Gussakovsky, E. E., Shpiegel, E., Nissim-Levi, A., Ratner, K., Ovadia, R., Giller, Y. E. \& Shahak, Y. (2001). Coloured shade nets can improve the yield and quality of green decorative branches of Pittosporum variegatum. Journal of Horticultural Science and Biotechnology, 76, $353-361$.

Pereira, F. H. F., Sá, F. V. S., Puiatti, M., Finger, F. L. \& Cecon, P. R. (2015). Crescimento de planta, partição de assimilados e produção de frutos de melão amarelo sombreado por diferentes malhas. Ciência Rural, 45, 1774-1781. http://dx.doi.org/10.1590/0103-8478cr20141134

Pereira, A. M., Queiroga, R. C. F., Pereira, F. H. F., Silva, Z. L. \& Santos, E. F. (2017). Characteristics of muskmelon fruits in relation to temporary row cover and the number of fruits. Horticultura Brasileira, 35, 591-598. https://dx.doi.org/10.1590/s0102-053620170418

Queiroga, R. C. F., Puiatti, M., Fontes, P. C. R. \& Cecon, P. R. (2009). Características de frutos de meloeiro variando número e posição de frutos na planta. Horticultura Brasileira, 27, 23-29. http://dx.doi.org/10.1590/S0102-05362009000100005

Santos, F. G. B., Negreiros, M. Z., Medeiros, J. F., Nunes, G. H. S., Medeiros, D. C. \& Grangeiro, L. C. (2015). Produção e qualidade de melão Cantaloupe em cultivo protegido temporariamente com agrotêxtil em Mossoró, Rio Grande do Norte. Revista Ceres, 62, 093-100.

Saraiva, G. F. R. \& Rodrigues, J. D. Influência do uso de malhas de sombreamento azul, vermelha e preta no desenvolvimento inicial de pepino taiko. UNESP, 2012. 16 p. (Monografia) - Universidade Estadual Paulista "Júlio de Mesquita Filho" Instituto de Biociências Campus.

Silva, M. A., Albuquerque, T. G., Alves, R. C., Oliveira, M. B. P. P. \& Costa, H. S. (2018). Melon (Cucumis melo L.) by-products: potential food ingredients for novel functional foods? Trends in Food Science \& Technology. 98, 181-189. https://doi.org/10.1016/j.tifs.2018.07.005

Stanghellini, C., Dai, J. \& Kempkes, F. (2011). Effect of near-infrared-radiation reflective screen materials on ventilation requirement, crop transpiration and water use efficiency of a greenhouse rose crop. Biosystems Engineering. 110, 261-271.

Taiz, L. \& Zeiger, E. Fisiologia vegetal. (6a ed.), Artemed, 2017. 888p.

Tafoya, F. A., Juárez, M. G. Y., Orona, C. A. L., López R. M., Alcaraz, T. J. V. \& Valdés, T. D. (2018). Sunlight transmitted by colored shade nets on photosynthesis and yield of cucumber. Ciência Rural, 48, 1-9. 2018. http://dx.doi.org/10.1590/0103-8478cr20170829 